\title{
Correspondence
}

\section{Soft cataracts: aspiration-irrigation by push-pull coupled syringes}

TO THE EDITOR British fournal of Ophthalmology

SIR, I was interested to read of the useful improvements by Bhargava and Gupta (1975) on the original apparatus described by Phillips and Wang (r97I).

The tubing attached to the push-pull machine I am now using has been considerably simplified by a different method: only standard items are employed, they are available already sterilized, and they are disposable. The use of Portex 'disposable manometer line, luer fitting, length $150 \mathrm{~cm}$, ref. no. 200/490/150' allows the application of no. 23 and no. 25 standard wire gauge needles without modification: the male end of the tubing ('manometer line') incorporates a length of stiff transparent plastic which constitutes a reasonably satisfactory handle for the needles. The other end

\section{The biter bit}

TO THE EDITOR British Yournal of Ophthalmology

SIR, I have just read Mr W. O. G. Taylor's account with interest (Taylor, 1975) having had a similar experience myself.

About four years ago I was sitting at my desk seeing patients in Outpatients Department at the Oxford Eye Hospital, when at precisely 12.0 o'clock on a Thursday morning something shot across my vision as though it had come from a catapult, and a dark spot followed by a comet's tail of opacities settled down in the lower field of my right eye. At first nothing could be seen apart from the vitreous opacity. I was later seen by $\mathrm{Mr}$ Lorimer Fison who discovered a hole at 9.0 o'clock in the periphery of the retina of the right eye. I was admitted to Moorfields Eye Hospital for treatment with the cryoprobe, which was done under local anaesthesia only. The cryo-application was painless, although the speculum was uncomfortable.

\section{Correction}

Egerer, I., and Freyler, H. Atypical cotton-wool spots, Brit. F. Ophthal. (1975) 59, 350.

Material and methods (second paragraph should read): The recording of the fluorescein angiography was (the female) can be applied easily to standard disposable syringes.

Yours faithfully, C. I. PHILLIPS

University of Edinburgh,

University Department of Ophthalmology,

Princess Alexandra Eye Pavilion,

Chalmers Street,

Edinburgh $\mathrm{EH}_{3}{ }_{9} \mathrm{HA}$,

Scotland

7 October I 975

\section{References}

BHARgaVA, s. K., and GUPTA, R. (1975) Brit. $\mathcal{F}$.

Ophthal., 59, 343

PHILlips, c. I., and WANG, M. K. (1971) Brit. $\mathcal{F}$.

Ophthal., 55, 36r

Apart from seeing floaters I have had no further trouble. It is interesting to note that immediately postoperatively there was a clear entoptic picture of the retinal vessels near the macula and a slight increase in refraction from emmetropia to +0.5 which has never completely gone. I still induce entoptic images of my retinal vessels very easily in this eye whenever light shines in from my right. I assume this is due to the depigmentation around the site of the cryo-application allowing stray light to enter the eye.

Yours faithfully, A. C. L. HOULTON

Felstead House, 23 Banbury Road, Oxford $\mathrm{OX}_{2} 6 \mathrm{NX}$ 28 November 1975

\section{Reference}

TAYLOR, w. o. G. (1975) Brit. F. Ophthal., 59, 392 accomplished using a Zeiss fundus camera, and a blue exciting filter (Kodak Wratten 47) and a yellow barrier filter (Schott-GG 14.3) was incorporated; for the recording a Kodak Plus-X Pan 36 film was selected. 